\title{
Influence of Induced Growth Patterns on Green Yield Components of Amaranthus cruentus L.
}

\author{
O. A. Awe ${ }^{1 *}$ and O. S. Osunlola ${ }^{2}$ \\ 'Department of Agricultural Technology, Federal College of Land Resources Technology, Kuru PMB 2035, \\ Jos 930001, Nigeria; adeoawe@gmail.com \\ 2Department of Crop Protection \& Environmental Biology, University of Ibadan, Ibadan, Nigeria; \\ Email address: remyosunlola@yahoo.com
}

\begin{abstract}
The influence of induced growth patterns on the yield of Amaranthus cruentus L. (Large Green variety) was investigated in the 2009 and 2010 early cropping seasons at the Federal College of Land Resources Technology, Kuru, Nigeria. Four growth patterns (periodic harvesting without cut back, cut back at $10 \mathrm{~cm}$ from the base of the stem, cut back at $20 \mathrm{~cm}$ from the base of the stem and continuous removal of inflorescence) were compared in a randomized complete block design with five replicates. The three induced growth patterns enhanced shoot regrowth and development of leaves and branches. In the 2009 trial, green yield from the cut back at $10 \mathrm{~cm}\left(9.22 \mathrm{tha}^{-1}\right)$ was significantly $(\mathrm{P}<0.05)$ different from the yield obtained under natural growth conditions and continuous removal of inflorescence. For the 2010 early season trial, the green yield from cut back at $10 \mathrm{~cm}\left(8.55 \mathrm{t} \mathrm{ha}^{-1}\right)$ was significantly different from the yield for cut back at $20 \mathrm{~cm}\left(6.07 \mathrm{t} \mathrm{ha}^{-1}\right)$. Floral initiation which was delayed by 29 days (2009) and 21 days (2010) after cutting the stem at $10 \mathrm{~cm}$ from the base prolonged the proliferation of branches. The lowest number of branches and weight of leaves were recorded under natural growth conditions in the two trials. The findings in this study indicate that Amaranthus cruentus growers could adopt the method of cutting back the stem at $10 \mathrm{~cm}$ from the base at 21 days after transplanting in order to take full advantage of the yield potential of the crop.
\end{abstract}

Keywords: Amaranthus cruentus, Growth Pattern, Cut Back, Number of Branches, Weight of Leaves.

\section{Introduction}

Amaranthus cruentus is grown widely in humid tropical Africa for the green leaf. The crop is one of the few leaf vegetables that can be used to improve the nutrition and income of rural farming families because of its high nutritional quality, ease of establishment and potential for good yields with low level of inputs. It is a fast growing annual plant that is ready for consumption from 4-6 weeks after planting. The draught tolerant characteristics of Amaranth make it a prospective dry land crop for farmers in semi-arid areas [1]. Amaranth seed and leaf are good sources of vitamins (A, K, B6, C, riboflavin, folate) and dietary minerals ( $\mathrm{Ca}, \mathrm{Fe}, \mathrm{Mg}, \mathrm{P}, \mathrm{K}, \mathrm{Zn}, \mathrm{Cu}$, $\mathrm{Mn}$ ). The seeds and leaves are high in protein. Protein content of the cultivated A. cruentus is estimated at $16 \%$ [2]. A. cruentus contains the essential elements that are absent in wheat, oats and rice. Regular consumption of A. cruentus helps in reducing blood pressure and cholesterol level. Apart from the nutritious green parts of the plant, the grains of $A$. cruentus also have economic value. A. cruentus has an erect growth habit and can grow up to a height of $1.2 \mathrm{~m}$ if it is not disturbed through harvesting.

${ }^{*}$ Corresponding author:

O. A. Awe (adeoawe@gmail.com) 
Amaranthus growers harvest $A$. cruentus by uprooting the young plants or cutting the leaves and tender branches of the growing mature plants periodically. Periodic harvesting by cutting the branches and leaves over several weeks tends to result in higher total yield. This method of harvesting is similar to pruning. Pruning is the process of cutting back plants to keep them within desired boundaries and promote bushier growth. Cut back of main stem in leaf vegetables enhances shoot regrowth. The position of the cut may also influence the rate of shoot regrowth. With the uprooting method of harvesting A. cruentus, farmer has to replant 3-4 times during the growing season. This implies additional work for seed bed preparation and field management. Periodic harvesting of leaves and branches on the other hand delays the initiation of flowering and increases growth in the vegetative phase. This method stimulates shoot regrowth and production of more leaves and branches thus resulting in higher green yield per plant and higher farmer income.

For commercial production, it is necessary to explore ways of enhancing the performance of the crop not only through fertilization but also through modifications in the growth pattern. The natural growth patterns of plants when altered or modified artificially affect growth significantly. Crops like A. cruentus which regrow naturally when harvested by cutting the branches and leaves periodically is a good example of crops that shows this growth behavior. In a study on okra by Olasantan and Salau [3], pruning significantly $(\mathrm{P}<0.05)$ delayed fruiting by $8-10$ days, extended length of harvest duration by $12-15$ days and increased number of pods/plant by $10-40 \%$ and pod yield by $9-36 \%$ more than the control plants which had neither apical bud removal nor pruning. Apical debudding of okra resulted in increased vegetative development, enhanced dry matter accumulation and reduced plant height [4].

The influence of growth patterns due to modification of plant height in leaf vegetable has not received serious research attention in Nigeria. This can be attributed to the fact that growers tend to be satisfied with the conventional production and harvesting methods used in small portions of land. The common methods include uprooting the young plants and cutting back the main stem at a height of about $15 \mathrm{~cm}$ from the base to encourage lateral growth [5], stimulate shoot regrowth and allow regular harvesting over a long period of about 6-8 weeks. Some growers cut the stem at ground level at about one month after transplanting and pick the leaves and branches every two weeks for about two months. Frequent harvesting of leaves and shoots delays the onset of flowering thereby prolonging the harvest period [6]. A low level cutting $(20 \mathrm{~cm}$ from the base) stimulates the development of new strong shoots while cutting close to the top of the plant produces weaker shoots that may start flowering at an early stage [7].

With the increasing need for improved nutrition through daily consumption of fruits and leaf vegetables it becomes necessary to explore ways of increasing the production and yield per unit area of land for vegetables like A. cruentus which have high nutritional and medicinal value. This study was designed to investigate the influence of natural and induced growth patterns on green yield components of A. cruentus $\mathrm{L}$.

\section{Materials and Methods}

The study was conducted at the Teaching and Research farm of the Federal College of Land Resources Technology, Kuru during the 2009 and 2010 cropping seasons. Kuru is located on the Jos Plateau (Latitudes $8^{\circ} 50^{\circ} \mathrm{N}$ and $10^{\circ} 10^{\prime}$ $\mathrm{N}$ and Longitudes $8^{\circ} 22^{\prime} \mathrm{E}$ and $9^{\circ} 30^{\prime} \mathrm{E}$ ). Jos Plateau is in the northern Guinea savannah vegetation zone. The mean annual rainfall of Kuru varies between $137.75 \mathrm{~cm}$ and 146.0 $\mathrm{cm}$. The experiment was laid out in a randomized complete block design consisting of four treatments and five replicates. Plot size was $2.5 \mathrm{~m} \mathrm{x} 3.0 \mathrm{~m}$. A bed measuring $2.5 \mathrm{~m} \mathrm{x}$ $3.0 \mathrm{~m}$ was made for each plot with a height of about $30 \mathrm{~cm}$. The bed was divided into two equal halves $(1.25 \mathrm{~m} \mathrm{x} 3.0 \mathrm{~m})$ to facilitate field operations. Five soil samples were collected with an auger at a depth of $0-15 \mathrm{~cm}$ for routine soil analysis to determine soil physical and chemical properties. Decomposed poultry droppings were applied to the field at the rate of $20 \mathrm{tha}^{-1}$. Each plot received $15 \mathrm{~kg}$ poultry droppings. The decomposing manure was worked into the soil and left for 14 days to ensure proper decomposition before transplanting the seedlings. A. cruentus, Large Green variety was used for the study. Seeds of the variety were sown in three nursery beds measuring $1 \mathrm{~m} \mathrm{x} 2 \mathrm{~m}$ in drills $10 \mathrm{~cm}$ apart. The seedlings were transplanted at 21 Days After Planting (DAP) at a spacing of $40 \mathrm{~cm} \mathrm{x} 20 \mathrm{~cm}$. Two to three seedlings were transplanted into each stand and thinned to one after seven days giving a total of 90 plants per plot. At 21 DAP the treatments applied were: 1.Periodic harvesting without cut back, 2.Cut back at 10 $\mathrm{cm}$ from the base of stem and periodic harvesting, 3.Cut back at $20 \mathrm{~cm}$ from the base of stem and periodic harvesting and 4.Continuous removal of inflorescence and periodic harvesting. 
Weeds were controlled regularly by hand pulling. There were no pest or disease problems on the field during the experiment. Variables assessed include green yield, number of branches (10 cm long and above) and weight of leaves ( $5 \mathrm{~cm}$ long and above). For the removal of inflorescence treatment, all the flowers on each plant were removed at 4-day interval. Harvesting of leaves and branches was done every 10 days ( $1^{\text {st }}, 2^{\text {nd }}$ and $3^{\text {rd }}$ harvest) and every 7 days (4th, 5th, 6 th harvest) from 30 days after transplanting. The number of branches $(10 \mathrm{~cm}$ long) and above was counted at each harvest. The leaves on the harvested branches $\left(4^{\text {th }}, 5^{\text {th }}\right.$ and $6^{\text {th }}$ harvest) for each treatment measuring $5 \mathrm{~cm}$ long and above were gathered together for leaf weight assessment. In A. cruentus, leaves and branches make up the green yield. Treatment means were analyzed with the Analysis of Variance technique following the procedure of Gomez and Gomez [8]. The means were separated using the Least Significant Difference (LSD) technique at $5 \%$ probability level.

\subsection{Soil Analysis}

Before planting in 2009 and 2010, soil chemical properties were determined from bulked composite soil samples collected from the experimental fields at $0-15 \mathrm{~cm}$ depth. The samples were air dried, crushed and sieved with a 2 $\mathrm{mm}$-mesh sieve. Soil $\mathrm{pH}$ was determined electrometrically using a 1:2 soil/ $\mathrm{H}_{2} \mathrm{O}$ ratio. Percentage organic matter was calculated by multiplying the value obtained for organic carbon by 1.724 (Van Bemmelar factor). The \% organic carbon was determined by the dichromate oxidation procedure. Total $\mathrm{N}$ was determined by the Kjeldahl method. Available soil $\mathrm{P}$ was determined by the colorimetry method after Bray P-1 extraction [9]. Exchangeable bases $(\mathrm{K}, \mathrm{Na}, \mathrm{Ca}$, and $\mathrm{Mg}$ ) were extracted with neutral Ammonium acetate solution. $\mathrm{K}$ and $\mathrm{Na}$ were determined on a flame photometer. EDTA titration procedure was used to determine the levels of $\mathrm{Ca}$ and $\mathrm{Mg}$.

\section{Results and Discussion}

The results of the soil analyses at the sites of the experiment during the 2009 and 2010 rainy seasons are presented in Table 1. The soil at the first (2009) site is loam while that of the second site is sandy clay loam. The two fields are low in the major nutrients. $\mathrm{pH}$ values are 6.2 (2009) and 5.6 (2010). Green yield results (Table 2) in the two trials indicate that the induced growth patterns influenced the total yield of the Large Green A. cruentus variety. In the
Table 1. Chemical and physical properties of the soil at the experimental sites

\begin{tabular}{|c|c|c|}
\hline & 2009 & 2010 \\
\hline Soil property & Mean* & Mean* \\
\hline $\mathrm{pH}\left(\mathrm{H}_{2} \mathrm{O}\right)$ & 6.2 & 5.6 \\
\hline $\mathrm{pH}\left(0.01 \mathrm{M} \mathrm{CaCl}_{2}\right)$ & 6.0 & 4.4 \\
\hline Organic carbon (\%) & 1.58 & 0.89 \\
\hline Total N (\%) & 0.025 & 0.140 \\
\hline Available P (ppm) & 5.95 & 3.50 \\
\hline $\begin{array}{l}\text { Exchangeable K } \\
\left(\mathrm{Cmol} \mathrm{kg}^{-1}\right)\end{array}$ & 0.37 & 0.43 \\
\hline $\begin{array}{l}\text { Exchangeable } \mathrm{Na} \\
\left(\mathrm{Cmol} \mathrm{kg}^{-1}\right)\end{array}$ & 0.33 & 0.20 \\
\hline $\begin{array}{l}\text { Exchangeable Ca } \\
\left(\mathrm{Cmol} \mathrm{kg}^{-1}\right)\end{array}$ & 2.23 & 4.20 \\
\hline $\begin{array}{l}\text { Exchangeable } \mathrm{Mg} \\
\left(\mathrm{Cmol} \mathrm{kg}^{-1}\right)\end{array}$ & 1.01 & 1.08 \\
\hline $\mathrm{H}+\mathrm{Al}$ & 1.2 & 1.33 \\
\hline $\mathrm{ECEC}\left(\mathrm{Cmol} \mathrm{kg}^{-1}\right)$ & 5.14 & 9.60 \\
\hline Clay (\%) & 27 & 24 \\
\hline Silt (\%) & 36 & 12 \\
\hline Sand (\%) & 37 & 64 \\
\hline Textural class & Loam & Sandy clay loam \\
\hline
\end{tabular}

${ }^{*}$ Average of five samples

Table 2. Green yield, number of branches and weight of leaves of the Large Green Amaranthus cruentus variety during the 2009 trial

\begin{tabular}{llcc}
\hline $\begin{array}{l}\text { Treatment (Growth } \\
\text { pattern) }\end{array}$ & $\begin{array}{c}\text { Yield* } \\
\left(\mathrm{t} \mathrm{ha}^{-1}\right)\end{array}$ & $\begin{array}{c}\text { Number } \\
\text { of } \\
\text { branches* }\end{array}$ & $\begin{array}{c}\text { Weight } \\
\text { of leaves* } \\
\left(\mathrm{kg} / 7.5^{2} \mathrm{~m}\right)\end{array}$ \\
\hline $\begin{array}{l}\text { A: Periodic harvesting } \\
\text { without cutting the } \\
\text { stem }\end{array}$ & $6.02^{\mathrm{a}}$ & 53.0 & $0.56^{\mathrm{a}}$ \\
$\begin{array}{l}\text { B: Cut back at } 10 \mathrm{~cm} \\
\text { from the base and } \\
\text { periodic harvesting }\end{array}$ & $9.22^{\mathrm{b}}$ & 276.2 & $1.72^{\mathrm{b}}$ \\
$\begin{array}{l}\text { C: Cut back at } 20 \mathrm{~cm} \\
\text { from the base and } \\
\text { periodic harvesting }\end{array}$ & $7.28^{\mathrm{ab}}$ & 221.8 & $0.65^{\mathrm{a}}$ \\
$\begin{array}{l}\text { D: Continuous removal } \\
\text { of inflorescence and } \\
\text { periodic harvesting }\end{array}$ & $6.94^{\mathrm{a}}$ & 107.6 & $0.88^{\mathrm{a}}$ \\
$\begin{array}{l}\text { SE } \pm \\
\text { LSD }\end{array}$ & 0.95 & 16.64 & 0.13 \\
\hline
\end{tabular}

*Means followed by the same alphabet along the column are not significantly different at $5 \%$ probability level. 
2009 trial, cutting of main stem at $10 \mathrm{~cm}$ from the base followed by periodic harvesting gave the highest yield of $9.22 \mathrm{t} \mathrm{ha}^{-1}$. This yield was significantly $(\mathrm{P}<0.05)$ different from the $6.94 \mathrm{t} \mathrm{ha}^{-1}$ obtained for continuous removal of inflorescence and $6.02 \mathrm{t} \mathrm{ha}^{-1}$ obtained under natural growth conditions. The yields from the two cut back treatments at $10 \mathrm{~cm}$ from the base $\left(9.22 \mathrm{t} \mathrm{ha}^{-1}\right)$ and $20 \mathrm{~cm}$ from the base $\left(7.28 \mathrm{t} \mathrm{ha}^{-1}\right)$ were not significantly different. In the 2010 season, the highest yield $\left(8.55 \mathrm{t} \mathrm{ha}^{-1}\right)$ was given by the cut back at $10 \mathrm{~cm}$ treatment. This yield was significantly different from the yield values of the other treatments. In the two seasons of experimentation, growth under natural conditions gave the lowest green yields.

The findings indicate that there is yield advantage when the stem of the A. cruentus variety is cut back at 10 $\mathrm{cm}$ or $20 \mathrm{~cm}$ from the base at 21 DAP. Cut back in leaf vegetables delays the reproductive phase and prolongs vegetative growth. This enhances shoot regrowth because A. cruentus re-generates naturally when the branches and leaves are harvested. Flowering was earliest in the control treatment since the plants were allowed to grow naturally. The reproductive phase was also initiated early in the continuous removal of inflorescence treatment. Early floral initiation in the two treatments was due to the fact that the meristematic tissue was not disturbed by cutting the stem. This agrees with the report of Olasantan [6], where removal of apical bud on the main stem of okra delayed the first fruit harvest when compared to the undebudded control plants.

The mean number of branches $(10 \mathrm{~cm}$ long and above $/ 7.5 \mathrm{~m}^{2}$ ) was similarly influenced in the 2009 and 2010 experiments in the four treatments (Tables 2 and 3). The means obtained for the control and induced growth patterns were significantly $(\mathrm{P}>0.05)$ different in the 2009 trial. For the 2010 trial, there was a slight departure. The control treatment and continuous removal of inflorescence treatment were significantly different in their effect on the number of branches. Values given by cut back at 10 $\mathrm{cm}$ and $20 \mathrm{~cm}$ from the base were not significantly different. Leaves are borne on the branches hence the tendency is for number of leaves to increase with increase in number of branches. This will eventually translate to increased yield which is evident in the green yield result.

Number of branches is an indication of rate of shoot regrowth. Branches are important in A. cruentus because leaves are consumed with the tender branches. The point of cutting on main stem from the base seemed to influence rate of branch formation in the two cut back treatments.
Table 3. Green yield, number of branches and weight of leaves of the Large Green Amaranthus cruentus variety during the 2010 trial

\begin{tabular}{|c|c|c|c|}
\hline $\begin{array}{l}\text { Treatment (Growth } \\
\text { pattern) }\end{array}$ & $\begin{array}{l}\text { Yield* } \\
\left(\mathrm{t} \mathrm{ha}^{-1}\right)\end{array}$ & $\begin{array}{c}\text { Number } \\
\text { of } \\
\text { branches* }\end{array}$ & $\begin{array}{c}\text { Weight of } \\
\text { leaves* } \\
\left(\mathrm{kg} / 7.5 \mathrm{~m}^{2}\right)\end{array}$ \\
\hline $\begin{array}{l}\text { A: Periodic harvesting } \\
\text { without cutting the } \\
\text { stem }\end{array}$ & 4.20 & 42.2 & $0.69^{\mathrm{a}}$ \\
\hline $\begin{array}{l}\text { B: Cut back at } 10 \mathrm{~cm} \\
\text { from the base and } \\
\text { periodic harvesting }\end{array}$ & 8.55 & $271.0^{\mathrm{a}}$ & 1.66 \\
\hline $\begin{array}{l}\text { C: Cut back at } 20 \mathrm{~cm} \\
\text { from the base and } \\
\text { periodic harvesting }\end{array}$ & $6.07^{\mathrm{a}}$ & $233.0^{\mathrm{a}}$ & $0.64^{\mathrm{a}}$ \\
\hline $\begin{array}{l}\text { D: Continuous removal } \\
\text { of inflorescence and } \\
\text { periodic harvesting }\end{array}$ & $5.80^{\mathrm{a}}$ & 111.0 & 1.05 \\
\hline $\mathrm{SE} \pm$ & 0.60 & 21.12 & 0.10 \\
\hline $\operatorname{LSD}_{(0.05)}$ & 1.30 & 46.0 & 0.30 \\
\hline
\end{tabular}

* Means followed by the same alphabet along the column are not significantly different at $5 \%$ probability level.

Branch proliferation was more in the $10 \mathrm{~cm}$ cut back followed by the $20 \mathrm{~cm}$ cut back. The delayed floral initiation in the $10 \mathrm{~cm}$ cut back enhanced branching.

In the result for the weight of leaves $(5 \mathrm{~cm}$ long and above) $/ 7.5 \mathrm{~m}^{2}$ (Tables 2 and 3), the 2009 trial mean (0.56 $\mathrm{kg} / 7.5 \mathrm{~m}^{2}$ ) for the control (natural growth condition) was significantly different from the mean $\left(1.72 \mathrm{~kg} / \mathrm{m}^{2}\right)$ given when the main stem was cut at $10 \mathrm{~cm}$ from the base followed by periodic harvesting. The means for the other two induced growth patterns (cut back at $20 \mathrm{~cm}$ and continuous removal of inflorescence) were however not significantly different. For the 2010 trial, the mean (1.66 $\mathrm{kg} / 7.5 \mathrm{~m}^{2}$ ) given when the main stem was cut at $10 \mathrm{~cm}$ from the base was significantly different from the means given by the control and the other two induced growth patterns. The control treatment and cut back at $20 \mathrm{~cm}$ from the base did not influence the weight of leaves significantly. More leaves were produced in the $10 \mathrm{~cm}$ cut back which gave the highest rate of branch regrowth as a result of delayed flowering which prolonged vegetative growth.

Normal flowering under natural growth conditions and continuous removal of inflorescence affected branching and reduced the rate of shoot regrowth which directly affected the formation of leaves and branches since vegetative 
growth stops at the beginning of reproductive phase. In the two cut back treatments, flowering was earlier in the treatment with cut back at $20 \mathrm{~cm}$ high by 29 days (2009) and 21 days (2010) when compared with cut back at $10 \mathrm{~cm}$. Cutting close to the meristematic tissue at the tip of the stem ( $20 \mathrm{~cm}$ cut back) probably had little effect in delaying the production of flowers which was delayed in the cut back at $10 \mathrm{~cm}$. This enabled plants in the $10 \mathrm{~cm}$ cut back treatment to continue vegetative growth producing more leaves and branches which increased green yield. These results agree with the reports of Olasantan [6] and Olasantan and Salau [5].

\section{Conclusion}

The findings in this study indicate that the yield of Amaranthus cruentus can be increased significantly if the main stem is cut back before periodic harvesting commences. The three induced growth patterns enhanced shoot regrowth and development of leaves and branches. Regular harvesting every 7-10 days appears to delay flowering and stimulates shoot regrowth and branch formation. Continuous removal of inflorescence prolonged the vegetative growth phase.

The results indicate that the yield of $A$. cruentus is affected by changes in its natural growth pattern. The two cut back treatments significantly $(\mathrm{P}<0.05)$ increased number of branches and total leaf weight resulting in higher green yield when compared to the natural growth and continuous removal of inflorescence treatments. Cut back of main stem at $10 \mathrm{~cm}$ from the base followed by periodic harvesting is recommended for economic production of $A$. cruentus since it delayed flowering and enhanced shoot regrowth. The findings in this study suggest that $A$. scruentus growers could adopt this production method in order to take full advantage of the yield potential of the crop.

\section{References}

1. Kauffman C S, and Weber L E (1990). Grain amaranth, Advances in new crops, Jannick J, and Simon J E (Eds.), Timber Press, Portland, OR, 127-139.

2. Olufolaji A O, and TayoT O (1980). Growth, development and mineral contents of three cultivars of Amaranthus cruentus L., Horticultural Science, vol 13 (2), 181-190.

3. Olasantan F O, and Salau A W (2008). Effect of pruning on growth, leaf yield and pod yields of okra (Abelmoschusesculentus L.) Moench), Journal of Agricultural Science, vol 146 (1), 93-102

4. Olasantan F O (1986). Effect of apical debudding on growth and yield of okra (Abelmoschusesculentus (L) Moench, Experimental Agriculture, vol 22(3), 307-312.

5. Olujide M G, and Oladele O I (2007). Economics of Amaranthus production under different NPK fertilizer regimes, Bulgarian Journal of Agricultural Science, vol 13, 225-229.

6. Palada M C, and Chang L C (2003). Suggested cultural practices for vegetable Amaranth, International Cooperators Guide, Asian Vegetable Research and Development Centre (AVRDC), AVRDC publication no. 03-552.

7. Schippers R R (2000). African indigenous vegetable: an overview of the cultivated species, Natural Resources Institute/ACP-EU Technical Centre for Agricultural and Rural Cooperation, Chatham, UK, 224.

8. Gomez K A, and Gomez A A (1984). Statistical procedures for agricultural Research, $2^{\text {nd }}$ Edn., John Wiley and Sons, Singapore.

9. Bray R H, and Kurtz L T (1945). Determination of total, organicandavailableformsofphosphorusinsoils, SoilScience, vol 59(1), 39-45. 